\title{
Erratum to: Genetic Screen for Genes Involved in Chk2 Signaling in Drosophila
}

\author{
Suk-Young Park, and Young-Han Song*
}

Erratum to: Mol. Cells 2008; 26(4), 350-355

This paper was initially submitted to Journal 'Molecules and Cells' by Suk-Young Park \& Young-Han Song. In the Materials and Methods section, "Large form" should be changed to "lokPB isoform reported in FlyBase". The revised full sentence is as follows:

\section{MATERIALS AND METHODS}

\section{Fly stocks and construction of transgenic flies}

Flies were grown on a standard cornmeal medium at $25^{\circ} \mathrm{C}$. Wild type and kinase dead (D286A) mutant forms of Drosophila Chk2 (lok-PB isoform reported in FlyBase) cDNAs were obtained by reverse transcription (RT)-PCR amplification from the wild type, Oregon R flies. cDNAs were cloned into pUAST vector and transgenic lines were generated by conventional gene transfer methods. EP lines were obtained from Exelixis. UASNotch was a gift of Dr. S. Artavanis-Tsakonas (Harvard Medical School). GMR-p35 was obtained from Bloomington Drosophila Stock Center and the ATM mutant fly was described previously (Song et al., 2004).

Ilsong Institute of Life Science, Hallym University, Anyang 431-060, Korea

*Correspondence: ysong@ @allym.ac.kr

Published online 19 February, 2014

The online version of the original article can be found under Mol. Cells 2008; 26(4), 350-355. 